\title{
THE INFLUENCE OF MENTORING ON WORK ENGAGEMENT AND THE RELATIONSHIP WITH THE SUPERIOR IN ORGANIZATIONS IN POLAND
}

https://doi.org/10.33141/po.2019.06.07

\section{Małgorzata Baran, Barbara A. Sypniewska Introduction}

$\mathbf{T}$ he increase in global competition requires organizations to adopt new strategies of human capital management. Undoubtedly, it is important to be able to verify which methods should be used in order to retain good employees and how to increase their engagement and motivation to work. Relationships between co-workers and their superiors have long been the core of knowledge about work environment and human resources management. Work engagement is a desirable state in any organization since it influences the quality of work, the degree of employees' satisfaction with work, and fulfilment of their aims, which translates into the success of the whole organization.

One of the increasingly valued methods of employee development is mentoring that becomes a practice which is widely used in contemporary organizations.

In this article, the authors strive to examine the influence of mentoring (and its various types) on employee work engagement. The purpose of this study is to identify the correlations between work engagement / relationships with the superiors (as regards: the possibilities for using the experience and knowledge of the best employees, the possibilities for addressing the superiors to seek assistance, and ease of making contact with the superior) and the type and aims of mentoring adopted in an organization. The following types of mentoring processes were taken into consideration: formalized, non-formalized, individual and group mentoring as well as intermentoring. The following were singled out as the goals of using mentoring: personal and professional development, taking up a job (i.e., onboarding before assuming a position), and preparation to a serving a new role in an organization (i.e., succession at work).

The article consists of two parts. The first part presents the phenomenon of mentoring and cites a variety of studies on the effects of mentoring. The second part of the article shows an analysis of the correlations among the above variables as well as conclusions drawn from literature review and empirical research ${ }^{1}$.

\section{Mentoring - characteristics and research review}

$\mathrm{n}$ deliberations on the influence of mentoring on employees' engagement, a definition is adopted, which shows the mentoring process from the perspective of all
Organization Review, No. 6, 2019, Vol. 953, pp. 52-59

www.przegladorganizacji.pl/en CScientific Society for Organization and Management (TNOiK)

its stakeholders and so the mentor, the mentee, and the organization in which mentoring is used: mentoring is a consciously implemented process of supporting people and organizations in accomplishment of set goals based on the mentee's potential and with the use of the mentor's competence and experience (Baran, 2018, p. 12).

The most widespread typology of mentoring is the division based on the number of participants in the mentoring process and their mutual relationships. The following may be singled out:

- individual mentoring - a traditional process based on the master-student relationship with one mentor and one mentee (Stokes, Merrick, 2013; Rowland, 2011),

- group mentoring - where one mentor leads several mentees that meet at the same time and ask questions, listen, and share their thoughts (Dixon, 2012, p. 9; Altus, 2015), - intermentoring - is a two-way mentoring process in which the participants in the mentoring relationship develop one another (Baran, 2013).

The use of different mentoring models is dependent on the nature of an organization and its strategic plans as well as developmental needs of the employees. The above factors also influence the structuring of the mentoring in place (Chao et al., 1992).

Informal mentoring is carried out spontaneously whereas a formal mentoring relationship is created as a result of a planned selection of mentors and mentees by an organization (Ragins, Cotton, 1999). A formal mentoring programme is often considered to be a structured and coordinated process using standard procedures, fixed plans, and determined goals (Hansford et al., 2003; Noe, 2002). Informal mentoring in turn is often seen as a process and a system of relationships between the mentor and mentee, which are spontaneous and interim in character (Megginson et al., 2006; Ragins, Cotton, 1999).

On the one hand, mentoring is an element of knowledge management in an organization, on the other hand, it is a widely used developmental tool for employees. Its use allows to obtain knowledge from experienced employees and faster onboard new and often younger ones or prepare them for new functions.

Therefore, participation in mentoring may be a chance for employees to improve their results at work, find adaptation to a group or organizational environment easier 
(Gibb, 1999), strengthen their work engagement, increase satisfaction from work, and achieve personal development (Lentz, Allen, 2009).

The benefits that organizations derive from mentoring have been widely defined in the literature, especially foreign literature, and supported by extensive research in foreign companies and organizations. Its influence on, among other things; better working conditions, more transparent succession of managers, preparation of leaders, greater motivation among employees, and loyalty of staff members has been well-argued. Wilson and Elman describe the process of mentoring not only as one that brings about benefits for an organization but also in the context of benefits that it offers mentors and mentees (Lankau, Scandura, 2007).

Empirical research proved the stability of the work satisfaction factor and its influence on employees' engagement which is independent of the workstation and it only incidentally changes depending on the enterprise type. It was demonstrated that the influence of "dedication” and „vigor" upon work satisfaction is stronger than „absorption" (Rakowska, Mącik, 2016). It should also be stressed that if you want to upkeep the engagement o employees, their organizations should take care of synchronization of employees' expectations and capabilities (Stankiewicz, Moczulska, 2014) and in this case it is mentoring that may contribute to it. Moreover, it should be emphasized that from the employees' point of view the possibilities of development and the employer's engagement make up important criteria of the organization choice in which s/ he would like to work (Jarka, Ruciński, 2017).

Empirical research was conducted on the positive effects of mentoring relationships for employees, as a result of which the effects can be divided into two categories, that is, the objective and subjective professional benefits. The objective benefits encompass remuneration and promotion (Allen et al., 2006; Eby et al., 2006) whereas the subjective effects are indicators of professional success such as: job satisfaction, work engagement, satisfaction with professional development, intention to change a job, and subjective assessment of the results at work - the sense of professional success (Lentz, Allen, 2009). Research results have shown that personal satisfaction and increased job satisfaction were the positive effects of mentoring (Hansford, Ehrich, 2006, p. 44). Chao et al. (1992) demonstrated that the participants in mentoring felt, among others, greater job satisfaction than the people who did not participate in it. Allen et al. also indicated positive influence of mentoring both on job satisfaction and work engagement (Allen et al., 2004; Noufou et al., 2014, p. 143; Robinson, Reio, 2012; Ghosh, Reio, 2013).

\section{Research methodology}

n the first quarter of 2017 a questionnaire-based quantitative study was carried out. The research questionnaire was sent to companies recorded in the databases of both universities (the database of enterprises cooperating with each university), which were selected according to the cri- terion of the number of employees (micro, small, medium and large company). The authors adopted the company size criterion according to the distribution reflecting the structure of companies in the population of enterprises in Poland (divided into micro, small, medium and large companies). Employees of companies that took part in the survey are a group of 1027 people. The self-employed persons were excluded from the study. The people who participated in the mentoring process in companies were singled out from the group under examination. There were 238 mentees $(23.9 \%)$ and 279 mentors $(28.0 \%)$. The results of the research presented in the article relate to the analysis carried out on a research sample of 238 mentees.

The purpose of the study was to identify the correlations between work engagement as well as relationships with the superiors (as regards: the possibilities for using the experience and knowledge of the best employees, the possibilities for addressing the superiors to seek assistance and ease of making contact with the superior) and the type and goals of mentoring adopted in an organization. The following types of mentoring processes were taken into consideration: formalized, non-formalized, individual and group mentoring as well as intermentoring. The following were singled out as the goals of using mentoring: personal and professional development, taking up a job (i.e., onboarding before assuming a position), and preparation to serving a new role in an organization (i.e., succession at work).

The following questions were formulated during the research process:

RQ1. What are the correlations between formalized / non-formalized mentoring and employee work engagement / employee relationships with the superiors?

RQ2. What are the correlations between individual mentoring / group mentoring/intermentoring and employee work engagement / employee relationships with the superiors?

RQ3. What are the correlations between mentoring focused on personal and professional development / onboarding mentoring / mentoring preparing for succession and employee work engagement / employee relationships with the superiors?

Examination of mentoring and the relationship with the superior was carried out with a specially designed questionnaire, whereas the study on work engagement was based on the concept authored by Schaufeli and Bakker (2003). Work engagement is understood as a positive, fulfilling feeling towards work, which is connected with the state of mind and comprised of three dimensions: the sense of vigour experienced by an employee, dedication to work, and absorption. Engagement was studied with the Polish version of the Utrecht Work Engagement Scale (UWES) containing nine statements determining three dimensions defined as (Schaufeli, Bakker, 2003): vigour (experiencing a high level of energy at work, willingness to go the extra mile, and resilience, especially in the face of adversities); dedication (working with enthusiasm, having the sense that one's work is important, and taking pride in being able to do one's job); absorption (the sense of full concentration on and involvement in work accompanied by experiencing the sense of unnatural passing of the time). 
Formalization of mentoring, type of mentoring, and the goals of mentoring were analysed as independent variables.

In the statistical analysis, the correlations between the variables singled out as described above and work engagement / the possibility to draw from the knowledge and experiences of the best employees / the possibility to address the superior to seek assistance / ease of contact with the superior were examined.

The correlations between the type / goals of mentoring (i.e., individual, group or intermentoring) and work engagement were examined with single factor variance analysis. Whereas correlations between the type / goals of mentoring (i.e., individual, group or intermentoring) and the possibility of drawing from the knowledge and experiences of the best employees / the possibility of addressing the superior to seek assistance / ease of contact with the superior were analysed with the independence test $\chi 2$.

The values of the statistically significant independence tests were supplemented with V-Cramer effect sizes and the values of statistically significant results of variance analysis - with effect sizes $\eta 2$. In line with the relevant literature (Cohen, 1988), interpretation of the $\mathrm{V}$ effect size depends on the number of groups that the objects are divided into by the variables under examination. With division into two groups, value 0.10 is a weak effect, value 0.30 - a moderate effect, and value 0.50 or above - a strong one. With a division into a larger number of groups, the values provided above must be divided by a root of product: (number of groups for the first variable -1 ) (number of groups for the second variable -1$)$. Whereas interpretation of the size $\eta 2$ is as follows: up to 0.06 - weak effect; 0.06-0.14 - moderate effect; over 0.14 - strong effect. IBM SPSS Statistic (version 25.0) was applied for statistical analysis.

\section{Empirical results and discussion on the results}

1 he statistical analysis in the next chapters will be focused on seeking correlations between the degree of formalization of mentoring / the type of mentoring / the goal of mentoring and work engagement / relationships with the superior.

The respondents who participated in three types of mentoring, that is, individual and group mentoring and intermentoring, were examined in the first place. Table 1 presents frequency distribution for the types of mentoring that the respondents participated in.

Table 1. Type of mentoring that the respondents participated in

\begin{tabular}{|c|c|}
\hline Type of mentoring & N \\
\hline individual mentoring & 217 \\
\hline group mentoring & 39 \\
\hline intermentoring & 109 \\
\hline
\end{tabular}

$\mathrm{n}$ - number of participants (the respondents could choose more than one answer)

Source: own work based on own study
The majority of the respondents participated in individual mentoring and intermentoring. Only $15 \%$ of respondents took part in all three types of mentoring. Another analysis was concerned with the goals of the mentoring process that the respondents participated in. Table 2 presents frequency distribution for the identified individual goals of mentoring.

Table 2. Type of concentration of individual mentoring that the respondents participated in

\begin{tabular}{|c|c|}
\hline $\begin{array}{c}\text { Type of individual mentoring } \\
\text { concentrated/focused on: }\end{array}$ & $\%$ \\
\hline Personal and professional development & 75.4 \\
\hline Onboarding & 64.3 \\
\hline Preparation to a new role in an organization & 70.1 \\
\hline
\end{tabular}

Source: own work based on own study

The largest number of the respondents who participated in mentoring focused on personal and professional development. $20 \%$ of employees took part in formalized mentoring while $80 \%$ of employees took part in non-formalized mentoring.

\section{The degree of formalization of mentoring versus work engagement and relationship with a superior}

An in-depth statistical analysis was carried out to seek correlations between formalized / non-formalized mentoring and work engagement. Table 3 presents mean work engagement indicators in a group of people participating in non-formalized mentoring and a group of people participating in formalized mentoring. The juxtaposition was supplemented with the values of independent sample Student's t-test.

Another analysis was concerned with identification of correlations between formalized / non-formalized mentoring and the possibility of using the experience and knowledge of the best employees.

Based on the independence test $\chi^{2}$, no statistically significant correlation was found between being a member of a group of participants in non-formalized mentoring or a group of participants in formalized mentoring and the possibility of using the experience and knowledge of the best employees, $\chi^{2}(3)=1.57, \mathrm{p}>0.05$.

The obtained research results show, however, that both the participants of formalized and non-formalized mentoring definitely had the possibility to use the knowledge and experience of the best employees of the company.

The next element of the study was the influence of the degree of mentoring formalization processes on the frequency of mentee contacts with the superior. The correlations between formalized / non-formalized mentoring and the possibility to address the superior to seek assistance with personal problems or to seek help were also analysed. Based on the independence test $\chi^{2}$, 
no statistically significant correlation was found, which indicates that the degree of formalization of mentoring processes is not significant for the frequency of employees addressing their superiors to seek assistance with problems.

In another statistical analysis, a correlation between formalized / non-formalized mentoring and the possibility of contacting the superior (such as: easy, requires some effort, significantly hampered, lack of onboard) was sought after.

Based on the test of independence $\chi^{2}$, no statistically significant correlation was found, $\chi^{2}(3)=2.69, \mathrm{p}>0.05$. The majority of the respondents $(72 \%)$ indicated that it was easy for them to contact the superior.

\section{Type of mentoring versus work engagement and relationships with a superior}

An in-depth statistical analysis was carried out to seek correlations between the type of mentoring (i.e., individual and group mentoring and intermentoring) and work engagement of the participants in mentoring. Table 4 presents mean work engagement indicators in a group of people participating in individual mentoring, a group of people participating in group mentoring, and a group of people participating in intermentoring. The juxtaposition was supplemented with the values of single factor variance analysis.
As far as the factors influencing work engagement are concerned, the average rank assigned to cooperation and mutual assistance between employees in a group of people participating in individual mentoring amounted to 7.54 with standard deviation of 3.86; in a group of people participating in group mentoring it was 7.62 with standard deviation of 3.61; and in a group of people participating in intermentoring it amounted to 7.69 with standard deviation of 3.51. Based on the Kruskal-Wallis $\mathrm{H}$ test, no statistically significant correlation was found, $\chi^{2}(2)=0.03, p>0.05$.

Next, correlations between the type of mentoring (i.e., individual, group and intermentoring) and the possibility to use the experience and knowledge of the best employees were under examination.

Based on the test of independence $\chi^{2}$, no statistically significant correlation among the variables under examination was found, $\chi^{2}(6)=7.36, \mathrm{p}>0.05$.

Based on the results of the respondents, it may be noted that as many as $80 \%$ of the participants in intermentoring point to using the knowledge and experience of other employees in an organization. The majority of the participants in individual mentoring (73\%) point to the possibility of using the knowledge and experience of the best employees. The least numerous group were the participants of group mentoring (66\%).

The correlations between the type of mentoring (i.e., individual, group and intermentoring) and the possibility

Table 3. Work engagement in a group of people participating in non-formalized mentoring and a group of people participating in formalized mentoring

\begin{tabular}{|c|c|c|c|c|c|c|c|}
\hline \multirow{3}{*}{ Work engagement } & \multicolumn{7}{|c|}{ Mentoring: } \\
\hline & \multicolumn{2}{|c|}{ Formalized } & \multicolumn{2}{|c|}{ Non-formalized } & \multirow[b]{2}{*}{$\mathbf{t}$} & \multirow[b]{2}{*}{ df } & \multirow[b]{2}{*}{ p } \\
\hline & $M$ & SD & $M$ & SD & & & \\
\hline Vigour & 10.88 & 3.73 & 10.91 & 3.69 & -0.05 & 363 & 0.961 \\
\hline Dedication & 12.29 & 3.86 & 12.57 & 3.61 & -0.58 & 363 & 0.566 \\
\hline Absorption & 11.87 & 4.10 & 11.67 & 3.75 & 0.39 & 363 & 0.694 \\
\hline Engagement & 35.04 & 10.48 & 35.15 & 9.78 & -0.08 & 363 & 0.939 \\
\hline
\end{tabular}

$M$ - mean; SD - standard deviation; $\mathrm{t}$ - $\mathrm{t}$-student test statistic; $\mathrm{df}$ - degree of freedom; $\mathrm{p}$ - two-tailed statistical significance Source: own work based on own study

Table 4. Work engagement in a group of people participating in individual mentoring, a group of people participating in group mentoring, and a group of people participating in intermentoring

\begin{tabular}{|c|c|c|c|c|c|c|c|c|c|}
\hline \multirow{3}{*}{ Work engagement } & \multicolumn{9}{|c|}{ Mentoring: } \\
\hline & \multicolumn{2}{|c|}{ Individual } & \multicolumn{2}{|c|}{ Group } & \multicolumn{2}{|c|}{ Intermentoring } & \multirow[b]{2}{*}{ f } & \multirow[b]{2}{*}{ df } & \multirow[b]{2}{*}{ p } \\
\hline & $M$ & SD & $M$ & SD & $M$ & SD & & & \\
\hline Vigour & 11.52 & 4.21 & 9.82 & 4.15 & 10.36 & 4.26 & 2.06 & 2.196 & 0.130 \\
\hline Dedication & 12.83 & 3.47 & 11.87 & 4.23 & 11.56 & 4.33 & 1.69 & 2.196 & 0.187 \\
\hline Absorption & 12.02 & 3.13 & 10.90 & 4.39 & 11.15 & 4.17 & 1.13 & 2.196 & 0.326 \\
\hline Engagement & 36.37 & 9.17 & 32.59 & 11.79 & 33.06 & 11.52 & 1.89 & 2.196 & 0.155 \\
\hline
\end{tabular}

$M$ - mean; SD - standard deviation; $\mathrm{f}$ - test value; $\mathrm{df}$ - degree of freedom; $\mathrm{p}$ - statistical significance Source: own work based on own study 
of addressing the superior to seek assistance with personal problems or to seek help were analysed next. Table 5 presents frequency distribution for the possibility of addressing the superior to seek assistance with personal problems or to seek help in a group of people participating in individual mentoring, a group of people participating in group mentoring, and a group of people participating in intermentoring.

Based on the independence test $\chi^{2}$, statistically significant correlations were found between being a member of a group of participants in individual mentoring / being a member of a group of participants in group mentoring / being a member of a group of participants in intermentoring and the possibility of addressing the superior with personal problems or to seek help, $\chi^{2}(4)=11.83, \mathrm{p}>0.05$.

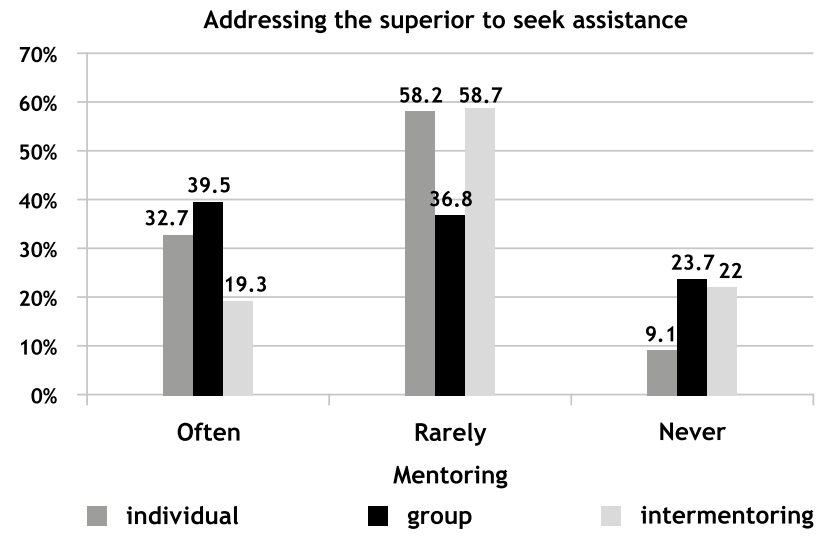

Figure 1. The possibility of addressing the superior to seek assistance in a group of people participating in individual mentoring, a group of people participating in group mentoring, and a group of people participating in intermentoring

Source: own work based on own study

The results show that people who participated in individual mentoring had the greatest possibility of addressing the superior. The participants in intermentoring had the least possibility (compare Figure 1). The obtained size effect was moderate, $\mathrm{V}=0.17$.

The correlations between the type of mentoring (i.e., individual, group and intermentoring) and the possibility of contacting the superior were under examination next.
Based on the independence test $\chi^{2}$, no statistically significant correlation was found between the possibility of contacting the superior and being a member of a group of participants in individual mentoring / being a member of a group of participants in group mentoring / being a member of a group of participants in intermentoring, $\chi^{2}(6)=9.00, p>0.05$.

In line with the study results, the respondents participating in individual mentoring, group mentoring, and intermentoring believed contact with the superior was easy, although it is noteworthy that the largest number of indications was clearly provided by the participants in intermentoring (63\%).

\section{Goals of mentoring versus work engagement of the mentee and the mentee's relationships with the superior}

The first in-depth statistical analysis was concerned with identification of the correlations between work engagement and three goals of mentoring regarding personal and professional development, taking up a job (onboarding), and preparation to a new role in an organization. Table 6 presents mean work engagement indicators in a group of people participating in mentoring focused on development, a group of people participating in mentoring focused on onboarding, and a group of people participating in mentoring focused on preparing for a new role. The juxtaposition was supplemented with the values of single factor variance analysis.

Statistically significant differences among all work engagement indicators were found. The size of the obtained effects was moderate and amounted to $\eta^{2}=0.06$ for vigour, $\eta^{2}=0.05$ for dedication, $\eta^{2}=0.08$ for absorption and $\eta^{2}=0.08$ for engagement. Based on the post hoc Gabriel test, it was verified that in the case of all the work engagement indicators, the mean values obtained in a group of people participating in mentoring focused on professional development were higher than the mean values obtained in a group of people participating in mentoring focused on onboarding, $p<0.05$. The remaining differences were statistically insignificant.

Table 5. The possibility of addressing the superior to seek assistance with personal problems or to seek help in a group of people participating in individual mentoring, a group of people participating in group mentoring, and a group of people participating in intermentoring

\begin{tabular}{|c|c|c|c|}
\hline \multirow{2}{*}{$\begin{array}{c}\text { The possibility of } \\
\text { addressing the superior }\end{array}$} & Individual & Group & Mentoring: \\
\cline { 2 - 4 } & $\%$ & $\%$ & 19.3 \\
\hline Often & 32.7 & 39.5 & 58.7 \\
\hline Rarely & 58.2 & 36.8 & 22.0 \\
\hline Never & 9.1 & 23.7 & 100 \\
\hline Total & 100 & 100 & $\%$ \\
\hline
\end{tabular}

Source: own work based on own study 
Table 6. Work engagement in a group of people participating in mentoring focused on development, a group of people participating in mentoring focused on onboarding, and a group of people participating in mentoring focused on preparing for a new role

\begin{tabular}{|c|c|c|c|c|c|c|c|c|c|}
\hline \multirow{3}{*}{$\begin{array}{c}\text { Work } \\
\text { engagement }\end{array}$} & \multicolumn{9}{|c|}{ Mentoring focused on: } \\
\hline & \multicolumn{2}{|c|}{ development } & \multicolumn{2}{|c|}{ onboarding } & \multicolumn{2}{|c|}{ a new role } & \multirow[b]{2}{*}{$f$} & \multirow[b]{2}{*}{ df } & \multirow[b]{2}{*}{$\mathrm{p}$} \\
\hline & M & SD & $M$ & SD & M & SD & & & \\
\hline Vigour & 11.02 & 3.39 & 8.71 & 4.27 & 9.57 & 3.88 & 4.40 & 2.142 & 0.014 \\
\hline Dedication & 12.69 & 3.75 & 10.64 & 4.07 & 11.25 & 4.05 & 3.41 & 2.142 & 0.036 \\
\hline Absorption & 12.56 & 3.15 & 9.88 & 4.10 & 10.80 & 4.35 & 5.86 & 2.142 & 0.004 \\
\hline Engagement & 36.27 & 9.07 & 29.24 & 10.67 & 31.63 & 11.17 & 5.75 & 142 & 0.004 \\
\hline
\end{tabular}

$M$ - mean; SD - standard deviation; $f$ - test value; $d f$ - degree of freedom; $p$ - statistical significance

Source: own work based on own study

The mean values of all the work engagement indicators were higher in the group of people participating in mentoring focused on professional development than in the group of people participating in mentoring focused on onboarding (compare Figure 2).

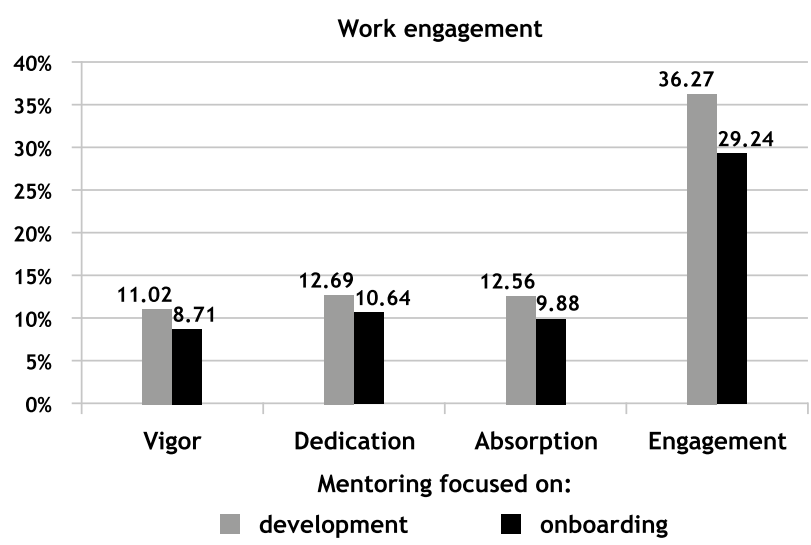

Figure 2. Mean work engagement indicators in a group of people participating in mentoring focused on development and a group of people participating in mentoring focused on onboarding Source: own work based on own study

As far as the factors influencing work engagement are concerned, the average rank assigned to cooperation and mutual assistance between employees in a group of people participating in mentoring focused on professional development amounted to 7.17 with standard deviation of 3.76 ; in a group of people participating in mentoring focused on onboarding it was 8.19 with standard deviation of 3.78 , and in a group of people participating in mentoring focused on preparing to a new role it amounted to 7.33 with standard deviation of 3.76. Based on the Kruskal-Wallis $\mathrm{H}$ test, no statistically significant correlation was found, $\chi^{2}(2)=1.56, \mathrm{p}>0.05$.

Another statistical analysis was concerned with the correlations between the possibility of using the experience and knowledge of the best employees and mentoring focused on personal and professional development, onboarding or preparation for a new role in an organization.
Based on the independence test $\chi^{2}$, no statistically significant correlation was found between the possibility of using the experience and knowledge of other employees and being a member of a group of participants in mentoring focused on development / being a member of a group of participants in mentoring focused on onboarding / being a member of a group of participants in mentoring focused on preparing to a new role, $\chi^{2}(6)=5.82, p>0.05$.

As indicated by research results, the largest number of the respondents who participated in mentoring focused on personal and professional development or onboarding had the possibility of using the experience and knowledge of other employees.

Another in-depth statistical analysis was concerned with identification of the correlations between the possibility of contacting the superior and the goals of mentoring that the respondents participated in (within a group of people participating in mentoring focused on development, a group of people participating in mentoring focused on onboarding, and a group of people participating in mentoring focused on preparing for a new role).

Based on the independence test $\chi^{2}$, no statistically significant correlation was found between a possibility of contacting the superior and being a member of a group of participants in mentoring focused on development / being a member of a group of participants in mentoring focused on onboarding / being a member of a group of participants in mentoring focused on preparing to a new role, $\chi^{2}(6)=5.23, p>0.05$.

In line with the study results, it was easy for the respondents participating in the mentoring process to contact the superior, regardless of the goal of mentoring.

\section{Summary and conclusions}

$T$ he in-depth statistical analysis was carried out in order to seek correlations between work engagement / relationships with the superiors (as regards: the possibilities for using the experience and knowledge of the best employees, the possibilities for addressing the superiors to seek assistance, and ease of making contact with the superior) and the type and aims of mentoring adopted in an organization. 
As a result of discovery of the correlations between work engagement and the three goals of mentoring concerning personal and professional development, taking up a job (onboarding), and preparation to a new role in an organization, statistically significant differences in terms of all the work engagements indicators have been found (RQ3). Mean values obtained in the group of participants in mentoring focused on personal and professional development were higher than mean values obtained in the group of participants in mentoring focused on taking up a job. This may mean that mentoring concerned not only with the professional but also with personal development has greater influence over employee work engagement in contrast to mentoring solely focused on taking up a job.

The correlations between formalized / non-formalized mentoring and a possibility to address the superior to seek assistance with personal problems or to seek help were also analysed (RQ1). As the research that was conducted proves, formalization of mentoring processes is not significant for the frequency of employees' contact with the superiors in order to seek assistance with problems, which is consistent with the theoretical assumptions. Moreover, the study showed that the majority of the respondents $(72 \%)$ indicated that it was easy for them to contact the superior.

The results of this study demonstrate that neither the degree of formalization of mentoring nor the type of mentoring (i.e., individual, group, and intermentoring) are significant for the degree of employee engagement in an organization (RQ1, RQ2).

As the relevant literature indicates, the process of mentoring is important for employee work engagement, so the above results are not surprising. The cited studies that are described in the literature indicate that despite of its type, mentoring positively influences a general shift in its participants' attitudes and work engagement (Dawley et al., 2010).

The respondents under examination that participated in both formalized and non-formalized mentoring definitely had a possibility to use the knowledge and experience of the best employees of the company. There are, however, no statistically significant differences between the two groups. As the analysis of the results regarding the goals of mentoring demonstrates, the largest group of employees that had a chance to use the knowledge and experience of the best employees were the participants of mentoring focused on personal and professional development and mentoring focused on onboarding. Based on the results obtained from the employees under analysis, it may also be noted that the participants of intermentoring were the ones who were the largest group pointing to using knowledge and experience of other employees (Baran, Sypniewska, 2017). This type of mentoring is frequently used as a form of involvement of experienced, older employees in the professional adaptation of newly employed workers. Simultaneously, it is an innovative method of internal training and onboarding on various positions in an organization. And the smallest group are the participants of group mentoring.
Next, the correlations between the type of mentoring (i.e., individual, group, and intermentoring) / the goals of mentoring relationships and ease of contact with the superior I a possibility to address the superior with problems were subject to analysis. In accordance with the survey results, the respondents who participated in individual or group mentoring or intermentoring believed it was easy for them to contact the superior, regardless of the goal of mentoring.

It is noteworthy, however, that clearly the largest number of indications was offered by the participants in intermentoring.

Unquestionably, the presented study has numerous limitations which include, among other things, a very narrow scope of the research. Nevertheless, despite visible limitations, the authors believe the study is important for people who are responsible for management. The study contributes to a better understanding of the nature of mentoring and its relationship with work engagement and relationships with the superior. Furthermore, due to lack of research on the variables under examination in this article, it may provoke further research.

\section{Małgorzata Baran, Ph.D., D.Sc. Collegium Civitas in Warsaw Management Department ORCID: 0000-0002-8081-9512 e-mail: malgorzata.baran@civitas.edu.pl}

Barbara A. Sypniewska, Ph.D.
University of Economics and
Human Sciences in Warsaw
Faculty of Management and Finance
ORCID: 0000-0001-8986-5606
e-mail: agata.sypni@op.pl

\section{Endnote}

1) This project was financed from the funds provided by the National Science Centre, Poland awarded on the basis of decision number DEC-2018/02/X/HS4/00772.

\section{References}

[1] Allen T., Eby L., Lentz E. (2006), Mentorship Behaviors and Mentoring Quality Associated with Formal Mentoring Programs: Closing the Gap between Research and Practice, "Journal of Applied Psychology", Vol. 91, No. 3, pp. 567-578.

[2] Allen T.D., Eby L.T., Poteet M.L., Lentz E., Lima L. (2004), Career Benefits Associated with Mentoring for Proteges: A Meta-analysis, „Journal of Applied Psychology”, Vol. 89, pp. 127-136.

[3] Altus J. (2015), Answering the Call: How Group Mentoring Makes a Difference, „Mentoring \& Tutoring: Partnership in Learning", Vol. 23, No. 2, pp. 100-115.

[4] Baran M. (2013), Intermentoring - korzyści zastosowania $w$ firmie, Zeszyty Naukowe Politechniki Łódzkiej, „Organizacja i Zarządzanie”, Vol. 1147, Nr 51, s. 269-273. 
[5] Baran M. (2018), Uwarunkowania skuteczności mentoringu w organizacji, Wydawnictwo Naukowe PWN, Warszawa.

[6] Baran M., Sypniewska B.A. (2017), The Significance of People-Oriented Management and Participation for Mentoring in Organizations, „Journal of Positive Management”, Vol. 8, No. 4, pp. 14-33.

[7] Chao G., Walz P., Gardner P. (1992), Formal and Informal Mentor Relationships: A Comparison on Mentoring Functions and Contrast with Non-mentored Counterparts, „Personnel Psychology”, Vol. 45, pp. 619-636.

[8] Cohen J. (1988), Statistical Power Analysis for the Behavioral Sciences ( $2^{\text {nd }}$ ed.), Lawrence Earlbaum Associates, Hillsdale, NJ.

[9] Dawley D.D., Andrews M.C., Bucklew N.S. (2010), Enhancing the Ties that Bind: Mentoring as Moderator, „Career Development International”, Vol. 15, pp. 259-278.

[10] Dixon P.M., (2012), Developing Organizational Cultural Competence through Mentoring: nboarding the Menttium Way [in:] P.M. Dixon, L.P. Sonda, K. Vappie (eds.), The Oxford Handbook of Organizational Socialization, Oxford University Press, New York.

[11] Eby L.T., Durley J.R., Evans S.C., Ragins B.R. (2006), The Relationship between Short-term Mentoring Benefits and Long-term Mentor Outcomes, "Journal of Vocational Behavior”, Vol. 69, No. 3, pp. 424-444.

[12] Ghosh R., Reio T.G. Jr (2013), Career Benefits Associated with Mentoring for Mentors: A Meta-analysis, „Journal of Vocational Behavior", Vol. 83, No. 1, pp. 106-116.

[13] Gibb S. (1999), The Usefulness of Theory: A Case Study in Evaluating Formal Mentoring Schemes, „Human Relations", Vol. 52, pp. 1055-1075.

[14] Hansford B., Ehrich L., Tennent L. (2003), Does Mentoring Deserve Another Look? [in:] R. Weisner, B. Millett (eds.), Human Resource Management: Challenges and Future Directions, John Wiley, Queensland.

[15] Hansford B., Ehrich L.C. (2006), The Principalship: How Significant is Mentoring? "Journal of Educational Administration”, Vol. 44, No. 1, pp. 36-52.

[16] Jarka S., Ruciński M. (2017), Rozwój koncepcji zarzqdzania wysokim zaangazowaniem pracowników organizacji - studia literaturowe, „Przegląd Organizacji”, Nr 10, s. $53-58$.

[17] Lankau M.J., Scandura T.A. (2007), Mentoring as a Forum for Personal Learning in Organizations, [in:] B.R. Ragins, K.E. Kram (eds.), The Handbook of Mentoring at Work: Theory, Research, and Practice, Thousand Oaks, CA, SAGE, pp. 95-122.

[18] Lentz E., Allen T.D. (2009), The Role of Mentoring: Others in the Career Plateauing Phenomenon, „Group \& Organization Management”, Vol. 34, pp. 358-384.

[19] Megginson D., Clutterbuck D., Garvey B., Stokes P., Garret-Harris R. (2006), Mentoring in Action, Kogan Page, London.

[20] Noe R.A. (2002), Mentoring: What We Know and Where We Might Go, „Research in Personnel and Human Resources Management”, Vol. 21, pp. 129-173.

[21] Noufou O., Rezania D., Hossain M. (2014), Measuring and Exploring Factors Affecting Students' Willingness to Engage in Peer Mentoring, „International Journal of Mentoring and Coaching in Education", Vol. 3, No. 2, pp. 141-157.

[22] Ragins B.R., Cotton J.L. (1999), Mentor Functions and Outcomes: A Comparison of Men and Women in Formal and Informal Mentoring Relationships, „Journal of Applied Psychology”, Vol. 84, No. 4, pp. 529-550.

[23] Rakowska A., Mącik R. (2016), Zaangażowanie pracownika a satysfakcja $z$ pracy - modelowanie zależności $z$ wykorzystaniem PLS-SEM, „Przegląd Organizacji”, Nr 5, s. $48-58$.

[24] Robinson D.M., Reio T.G. Jr (2012), Benefits of Mentoring African-American Men, „Journal of Managerial Psychology”, Vol. 27, No. 4, pp. 406-421.

[25] Rowland K.N. (2011), E-mentoring: An Innovative Twist to Traditional Mentoring, „Journal of Technology Management \& Innovation", Vol. 7, No 1, pp. 228-237.

[26] Schaufeli W.B., Bakker A.B. (2003), UWES-Utrecht Work Engagement Scale: Test Manual, Unpublished manuscript, Occupational Health Psychology Unit, Utrecht University, http://www.schaufeli.com, access date: 28.03.2019.

[27] Stankiewicz J., Moczulska M. (2014), Zaangażowanie pracowników i jego rola „druga strona”: pracoholizm i wypalenie zawodowe, „Przegląd Organizacji”, Nr 2, s. 25-30.

[28] Stokes P., Merrick L. (2013), Designing Mentoring Schemes for Organizations, [in:] J. Passmore et al. (ed.), The Wiley Blackwell Handbook of the Psychology of Coaching and Mentoring, John Wiley \& Sons Ltd., pp. 210-212.

\section{Wpływ mentoringu na zaangażowanie w pracę i relacje $z$ przełożonym w organizacjach w Polsce}

\section{Streszczenie}

Celem publikacji jest prezentacja wyników badania dotyczącego identyfikacji zależności pomiędzy zaangażowaniem w pracę, relacjami pracowników z przełożonym a rodzajem stosowanego mentoringu w organizacji i celami jego stosowania. Na podstawie uzyskanych wyników badania można stwierdzić, że mentoring skupiony na celu rozwoju zawodowego i osobistego ma większy wpływ na zaangażowanie w pracę niż mentoring skupiony na wprowadzeniu do pracy (tzw. stanowiskowy). Ponadto badania wskazują, że niezależnie od stopnia sformalizowania mentoringu (proces sformalizowany bądź niesformalizowany) oraz celu prowadzonego mentoringu kontakt z przełożonym był łatwy, a pracownicy mieli możliwość zwracania się z prośbą o pomoc do przełożonych $\mathrm{z}$ taką samą częstotliwością. Stwierdzono również, że największa grupa pracowników mająca możliwość korzystania $\mathrm{z}$ wiedzy i doświadczenia innych pracowników w organizacji to uczestnicy mentoringu rozwojowego oraz mentoringu stanowiskowego.

\section{Stowa kluczowe}

mentoring, zaangażowanie w pracę, relacje z przełożonymi, pracownicy 